\title{
Research on E-learning in College English Teaching in China Fu Bo ${ }^{1, a}$, Song Yinqiu ${ }^{1, b}$, Wang Yunxi ${ }^{1, c}$ \\ ${ }^{1}$ Jilin Agricultural University, College of Foreign Languages, Changchun, 130118, China \\ aivy510@126.com, byqsong1967@yahoo.com, ${ }^{\mathrm{c}} 275052245 @ q q . c o m$
}

Keywords: E-learning; college English teaching; knowledge platform; learners

\begin{abstract}
This paper aims to interprets the theoretical bases, characteristics and limitations of E-learning, the relationship between E-learning and college English teaching and learning. In terms of advanced English teaching in higher education, E-learning needs to establish a powerful platform of knowledge and information, meanwhile, it demands the online teachers linguistic competence and teaching capacity. E-learning integrates abundant teaching resources and sound communication environment together with friendly feedback approach, which supplies learners with a variety of colorful personalized learning materials and makes interactive learning realized easily and effectively. To some degree, E-learning can help cultivate English learners' autonomous learning consciousness and boost learning ability, as well as improve learners' intensive competence except for their listening and speaking ability, even their lifelong learning habits. With the aid of the innovative open application system, the overall level of education and teaching can be improved.
\end{abstract}

\section{Introduction}

With the rapid development and rising popularity of the multimedia and internet since 1990s, information technology has been changing all aspects of human society, such as the way of production, work, life and learning. For the past few years, such definitions as e-Business, e-Library, e-Bank and e-learning etc. are proposed in succession and gain prevalence globally, which truly reflects the the growing tendency mentioned above. By far, the main goal of the teaching reform in colleges and universities is to create a new teaching structure. Both modern information technology and curriculum integration can offer ideal teaching environment to the establishment of the new teaching structure.

What is vital importance for the teaching reform is how to carry out the integration of the information technology and a certain subject. English, an international language and a useful tool for communicating, deserves more attention in higher education when it is learned as a foreign language in China. The issue of combination of English teaching and learning and modern information technology has become the hot topic among English educators and education researchers. The ultimate aim of e-learning is to improve learning efficiency with the aid of technology, which makes the knowledge platform much plentiful than the traditional language teaching mode. However, E-learning can not take place of the traditional teaching and learning in the regular classroom, instead, it can extend time and space of traditional teaching and change the traditional mode. In turn, E-learning will definitely inspire learner's enthusiasm and improve the quality and efficiency of teaching.

\section{Definition and characteristics of E-learning}

What is e-learning? It is a new access to education to all, including new mechanism for communication and reciprocal action among people. With the rapid development of the Internet and multimedia technology, E-learning has become a new hot spot in current education field in terms of enriching teaching resources, which is also taken as a brand new way of social and educational interaction. After 10 years of development, E-learning follows the trend of lifelong learning and becomes mature from the perspectives of both technology and application. E-learning can not be interpreted by a single theory, but is a product by many related theories, such as constructivism 
theory which regards learning as the process of meaning construction; meta-cognitive strategy proposed by American psychologist Flavell; self-determination, namely, autonomous learning by Edward L. Deci and Richard M. Ryan; task-based learning; problem-based learning and muli-modal discourse in functional linguistics. All of these theories have be contributed to the concept of E-learning, and the factors in each theory are shown in Table1.

Table 1. Theoretical bases related to E-learning

\begin{tabular}{|l|l|l|l|l|}
\hline theory basis & elements & learners & teachers & learning mode \\
\hline constructivism & $\begin{array}{l}\text { context, cooperation, } \\
\text { dialogue, sense-making }\end{array}$ & learner-centered & $\begin{array}{l}\text { organizer, } \\
\text { guider, helper, } \\
\text { facilitater }\end{array}$ & $\begin{array}{l}\text { scaffolding/ } \\
\text { anchored/random } \\
\text { access instruction }\end{array}$ \\
\hline $\begin{array}{l}\text { meta-cognitive } \\
\text { strategy }\end{array}$ & $\begin{array}{l}\text { meta-cognitive } \\
\text { knowledge/monitoring/ } \\
\text { experience }\end{array}$ & learner-centered & $\begin{array}{l}\text { organizer, } \\
\text { guider, helper, } \\
\text { facilitater }\end{array}$ & $\begin{array}{l}\text { independent } \\
\text { learning }\end{array}$ \\
\hline $\begin{array}{l}\text { independent } \\
\text { learning }\end{array}$ & $\begin{array}{l}\text { active intention of the } \\
\text { learner }\end{array}$ & learner-centered & $\begin{array}{l}\text { organizer, } \\
\text { guider, helper, } \\
\text { facilitater }\end{array}$ & $\begin{array}{l}\text { independent } \\
\text { learning }\end{array}$ \\
\hline $\begin{array}{l}\text { task-oriented } \\
\text { learning }\end{array}$ & $\begin{array}{l}\text { pre-task; task circle; } \\
\text { post-task }\end{array}$ & learner-centered & $\begin{array}{l}\text { organizer, } \\
\text { guider, helper, } \\
\text { facilitater }\end{array}$ & $\begin{array}{l}\text { learning } \\
\text { by doing }\end{array}$ \\
\hline $\begin{array}{l}\text { problem-based } \\
\text { learning }\end{array}$ & $\begin{array}{l}\text { learners } \\
\text { authentic situation }\end{array}$ & learner-centered & $\begin{array}{l}\text { organizer, } \\
\text { guider, helper, } \\
\text { facilitater }\end{array}$ & $\begin{array}{l}\text { question-oriented } \\
\text { learning }\end{array}$ \\
\hline $\begin{array}{l}\text { multi-modal } \\
\text { discourse }\end{array}$ & modal; medium & learner-centered & $\begin{array}{l}\text { organizer, } \\
\text { guider, helper, } \\
\text { facilitater }\end{array}$ & $\begin{array}{l}\text { transition of } \\
\text { modal }\end{array}$ \\
\hline
\end{tabular}

The new communicating mechanism includes digital video, digital audio, e-mail, computer network, multimedia, professional content network, information search, e-library, computer imitation, online learning management system, distance learning and online classes and so on. E-Learning refers to the education and related services conducted with the basis of internet. Learners can learn anywhere and anytime by E-learning, which makes lifelong education for all possible. As is known, E-learning is characterized by abundant learning resources and flexible way for modern learning, so the design and development of effective learning resources have become the core of E-learning practice and research. The learning materials in E-learning have been under digital process and operated with digital equipment (MP3, MP4, smart-phone, multimedia computer etc.) and/or digital environment(digital satellite radio network, internet etc.).

E-learning possesses unique characteristics that traditional teaching have not. Due to E-learning, studying become most modern and open social activity in $21^{\text {st }}$ century. Flexibly and conveniently, learners can have E-learning anytime and anyplace, 24 hours a day and 7days a week, at home or in office. E-learning is really cost-benefit to transmit teaching contents or information, because the cost of hiring teachers or infrastructure construction will be dramatically reduced. Suppose 1000 learners need to be trained, and 30 learners every time and 5 days in all lectured by one teacher in traditional classroom, it will take 8 months to fulfill the training. E-learning is capable of provide all learners the newest knowledge information timely. E-learning users can draw up their learning plans and progress rate according to their own ability and learning basis in order to take good control of their learning process and have better understanding over the learning materials. Teacher-centered learning mode in a traditional way may be completely replaced by student-centered learning mode due to E-learning. Studies have shown that E-learning can help learners have better discussion and participation in the process of learning. The interactive way online consists of chatting room, email, BBS, case analysis, scene description, discussion groups, teachers' guidance, tips, FAQ and other tools. E-learning liberates learning cost from schools or corporations, since the materials overseas 
and cross areas can be obtained easily and feasibly.

However, E-learning has its own limitation compared with traditional approaches . It lessens interpersonal communication, emotional exchange and feeling share, especially between educators and learners, which is considered fairly vital in foreign language acquisition. As for the practice function, there is a long way to go in the field of E-learning. To obtain real knowledge and skill, learners ought to put it into practice in person and exert application in actual environment. E-learning either can not do well in cultivation on learners' inner personalities such as loyalty, willpower and cooperation.

\section{E-learning and college English teaching and learning}

Instructional model refers to the stable relationship and structure form among various elements during the process of teaching activities under the guidance of certain teaching ideas and theories. The essential teaching and learning elements consist of teacher, learner, teaching contents and instructional technology, which are organic integrity of being interactive and interconnected. It is E-learning that has created sound conditions for college English teaching reform.

Introducing the multimedia technology into English language teaching can not only improve learners learning effect but also break the constraints from the regular classroom teaching. learners' subjective initiative and individual potential can be fully developed, so teaching can be conducted in accordance with learners' aptitude. For example, when American cultural symbols are discussed in English class, learners can log in the internet to search for the related information about these symbols and teachers can offer more video, audio and pictures to reinforce learners' understanding. The superiority of electrical communication equipment such as television and smart-phone lie in its video and sound, which can draw learners' attention effectively. E-learning is based on the concept of interaction, and teaching interaction refers to the interaction between learners and teaching resources or learning environment. The interaction in E-learning is hierarchical and contains three levels of concept interaction, information interaction and operation interaction, which is shown in Fig.1.

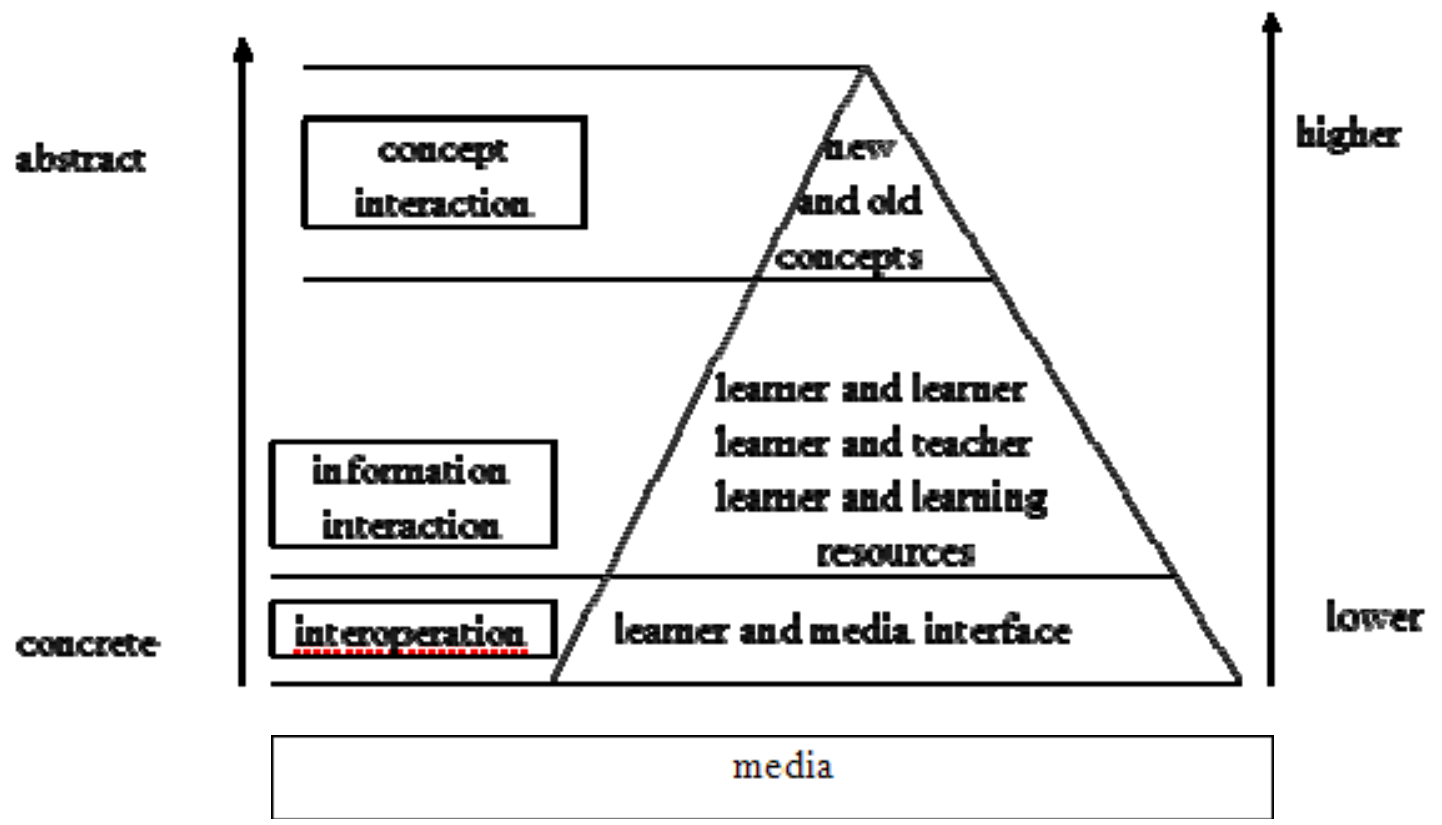

Fig.1. Hierarchical interaction modal in E-learning

The technology of CALL (computer-assisted language learning) supplies learners with the learning resources of nice trinity with sound, picture and context, so that learners can be exposed to the target language and cultural background. To learn English language with multimedia, learners must have the spirit of self-independence and new learning strategies. Traditional teaching and learning usually occurs in non-native language countries and teacher-dominated classroom, whereas E-learning model brings learners affluent resources full of pictures and texts, sound and images, 
which can stimulate learners' interest and create conditions for learners' independent learning. English learners can communicate with English speaking natives via chatting room or E-mail.

Learners can consolidate their communicating ability and become familiar with different cultures and reinforce necessary skills, such as listening, speaking, reading and reading. The learning environment based on network can weaken learners' excessive anxiety in learning and get positive and timely feedback for their questions, which benefit their confidence building. Chatting room and e-mail can facilitates communication between teachers and learners, and also improve learners' writing skill. Multimedia network teaching can enhance the accuracy and fluency of the learners' language acquisition.

E-learning is of great significance for English learners in colleges and universities, however, technology is teaching and learning method or tool. It is English teachers who determine the language teaching quality. E-learning can not totally take place of the regular teaching in the traditional way. E-learning should be combined with the traditional teaching method scientifically and reasonably, only in this way can promote learners' learning efficiency.

\section{Summary}

E-learning for English teaching and learning based on computer system and multimedia is a new English education mode, which can help college learners reach educational requirements. It takes advantage of internet and multimedia to set up ideal teaching platform that respects learners' specific learning needs. With rich resources and powerful functions, E-learning reflexes the principle of learners-center, teacher-guider publicly and orderly. Individualized teaching and independent learning help learners fulfill studying tasks and realize learning goals. E-learning can enhance students' consciousness of self-directed learning, improve their English listening, speaking, reading and writing ability.

To sum up, E-learning is characterized by globalization, network and economy. It is no doubt that it is a new focus of education development owning to technology. As English learners as concerned, E-learning is vivid through visualized data, learning environment full of images and sounds, lively and interesting, practical and easy-to-learn, plentiful learning resources online, time shortened to gain new information. It provides for both language teachers' teaching and learner's learning language, broadens learners' cultural horizon and helps them open the door towards the world. Though E-learning has much more advantages than the traditional teaching method, the traditional one should not be rejected. What we should do is to combine the modern information technology and traditional text-based teaching mode so that both teachers and learners can attain mutual development and improve overall teaching quality.

\section{References}

[1] Babak Ghasemi, Masoud Hashemi. ICT: Newwave in English language learning/ teaching J. Procedia Social and Behavioral Sciences (2011)

[2] Cappelli, Gregory, Scott Wilson, Michael Husman. E-learning: Power for the Knowledge Economy, Credit Suisse First Boston (2000)

[3] Loanne Snavely, Helen Smith. ACRL Eleventh National Conference, Bringing the Library to Students: Linking Customized Library Resources through a Course- Management System ( 2003)

[4] Kong K. A comparison of the linguistic and interactive features of language learning websites and textbooks J. Computer Assisted Language Learning(2009)

[5] Ken Beaty. Teaching and Researching Computer-assisted Language Learning M. Foreign Language Teaching and Research Press. (2007)

[6] Laurillard, D.Rethinking University Teaching: A Conversational Framework for the Effective Use of Learning Technologies(2nd edition) M. London: Routledge.(2001)

[7] Mayer, R.E.Multimedia Learning M. New York: Cambridge University Press.(2001) 